Univerzitet u Beogradu
Poljoprivredni fakultet
Institut za poljoprivrednu tehniku
Naučni časopis
POLJOPRIVREDNA TEHNIKA
Godina XLV
Broj 4, 2020.
Strane: $16-28$

\title{
DEVELOPMENT OF A MOTORISED PLANTAIN CHIPPING MACHINE AND PERFORMANCE EVALUATION USING RESPONSE SURFACE METHODOLOGY
}

\author{
Ukachi J. Etoamaihe $^{* 1}$, Sylvia O. Isaac ${ }^{2}$ \\ ${ }^{1}$ Department of Agricultural Engineering, Michael Okpara University \\ of Agriculture, Umudike, P. M. B. 7267, Umuahia, Abia State, Nigeria \\ ${ }^{2}$ Department of Mechanical Engineering, Abia State University, \\ Uturu, Abia State, Nigeria
}

\begin{abstract}
A motorised plantain chipping machine was developed. The machine is made up of a cutting device, a feeding mechanism, the support frame and an electric motor as a source of power. The cutting mechanism consists of the stainless steel blades, a connecting rod, a guide frame for the blades and pulleys. The blades are arranged perpendicular to the plantain tubers. During Performance Evaluation using Response Surface Methodology it was found that the chipping efficiency increased as the number of cutting blades are increased. Also the chipping efficiency increased with the speed of the machine but was not affected by the inclination angles of the blades. The linear effects of speed, the linear and quadratic effects of the number of blades significantly affected the chipping efficiency of the machine at $5 \%$ probability.
\end{abstract}

Key words: plantain, electric, motor, chipping, machine, response, surface, methodology

\section{INTRODUCTION}

Plantain is a basic food crop in developing countries, especially in Africa; it serves as one of the major foods for over 70 million people in the Continent. Plantain belongs to the family Musa Spp. and species of Musa paradisiacal and it originated from Southern Asia, [1].

\footnotetext{
"Corresponding Author. E-mail: etoamaihe.ukachi@ mouau.edu.ng
} 
In some parts of Africa such as Nigeria and Ghana, plantains are dried and made into flour; plantain meal forms important food stuffs with the following constituents; water $10.62 \%$ protein $3.55 \%$, fat $1.15 \%$, carbohydrate $81.67 \%$ and ash $3.01 \%$ [1] Plantain is a type of banana which is common in tropical regions. It is starchier and less sweet when compared to bananas. Plantains are usually served steamed, boiled or fried, although ripe plantains can be eaten raw. They are a rich source of antioxidants, vitamin B-6 and minerals, and their soluble fibred content may help ward off intestinal problems [2]. Plantain for local consumption plays an important role in food and income security and has the potential to contribute to national food security and reduce rural poverty [1] Plantains provide the essential minerals that help the body to function efficiently. A $50 \mathrm{gm}$ of sliced or cooked plantain has 49 milligrams of magnesium and 716 milligrams of potassium, giving the body 15 percent of the recommended daily intake for each of these minerals [3]. The body needs magnesium for proper muscle contraction and nerve function, while potassium is a crucial component in the body fluids. A cup 50gm of plantain flour contains 5 to 10 percent of the iron need of the body. Iron helps to carry oxygen through the bloodstream which serves as a benefit to the muscles of the body. Although raw plantain is bitter and starchy, some people like them raw. They are more nutritious raw, with about 10 percent more magnesium, phosphorus and potassium. A cup of $50 \mathrm{gms}$ raw plantains has 27 milligrams of thiamine, a B-vitamin that helps the body's cells use carbohydrates as energy and helps ensure the proper functioning of the heart muscles and the nervous system [2]. Plantain processed into flour can be stored for up to a maximum of two years [1]. The ripe fruit is pureed, candied, and preserved in various forms when not eaten fresh. The extracts are used in the manufacture of catsup, vinegar, and wine. The unripe fruit can be powdered or chipped.

Slicing operation is achieved by cutting, which involves rotation of thin sharp blade with different configurations and speeds through the materials resulting in minimum rupture and deformation of the materials [4]. Reducing the size of food raw materials is an important operation to achieve a definite size range [5]. The traditional method of cutting plantains into chips has been observed to cause drudgeries, prone to finger injury, time consuming, produces irregular sized chips, and inevitably leads to low output by processors. The existing plantain chipping machines when tested were found to produce irregular sized, broken and discoloured chips which make the products unacceptable. The commonest methods of chipping plantain in our localities today include the use of knife, wooden platform plantain slicer, and metal cutter. These methods have a lot of deficiencies in terms of chipping time, efficiency, quality and safety. In view of this, there is need to improve on the existing plantain chipping machines by use of electric motor powered and highly efficient machine as obtained by this developed slicer. The purpose of the machine is to make chipping process less laborious especially for medium scale industries and for domestic purposes.

The objectives of this study therefore include; to design and fabricate a motorized small scale plantain chipper. To test the developed chipper for performance during operation and to analyse the experimental results obtained using Response Surface Methodology. 


\section{MATERIAL AND METHODS}

\section{$\mathrm{T}$}

\section{Design Considerations}

he following considerations were made during the development of the machine: Develop a machine that can produce uniform sized chips without discoloration. Develop a machine that is smooth in operation with little noise.

To use locally available materials for its construction.

To develop a rigid and reliable machine when in operation.

\section{Description of the Machine}

The machine is made up of a cutting device, a feeding mechanism, the support frame and an electric motor as a source of power. The cutting mechanism consists of the stainless steel blades, a connecting rod, a guide frame for the blades and pulleys. The blades are arranged perpendicular to the plantain tubers. The feeding and the discharge mechanisms consist mainly of the Geneva drive mechanism meant to deliver intermittent motion to the conveyor, thereby causing the conveyor to move in a start-stop fashion. The drive shaft is supported by two ball bearings mounted on the base frame and which provide support for both radial and thrust loads. Plantains are fed into the hopper were they are discharged into the cutting chamber and are chipped by the cutting blades. The chips are discharged underneath the machine and are collected on a collector plate. Fig. 1 shows the orthographic drawing of the machine. Fig. 2 shows the orthographic model of the machine, while Fig. 3 shows the actual developed machine.
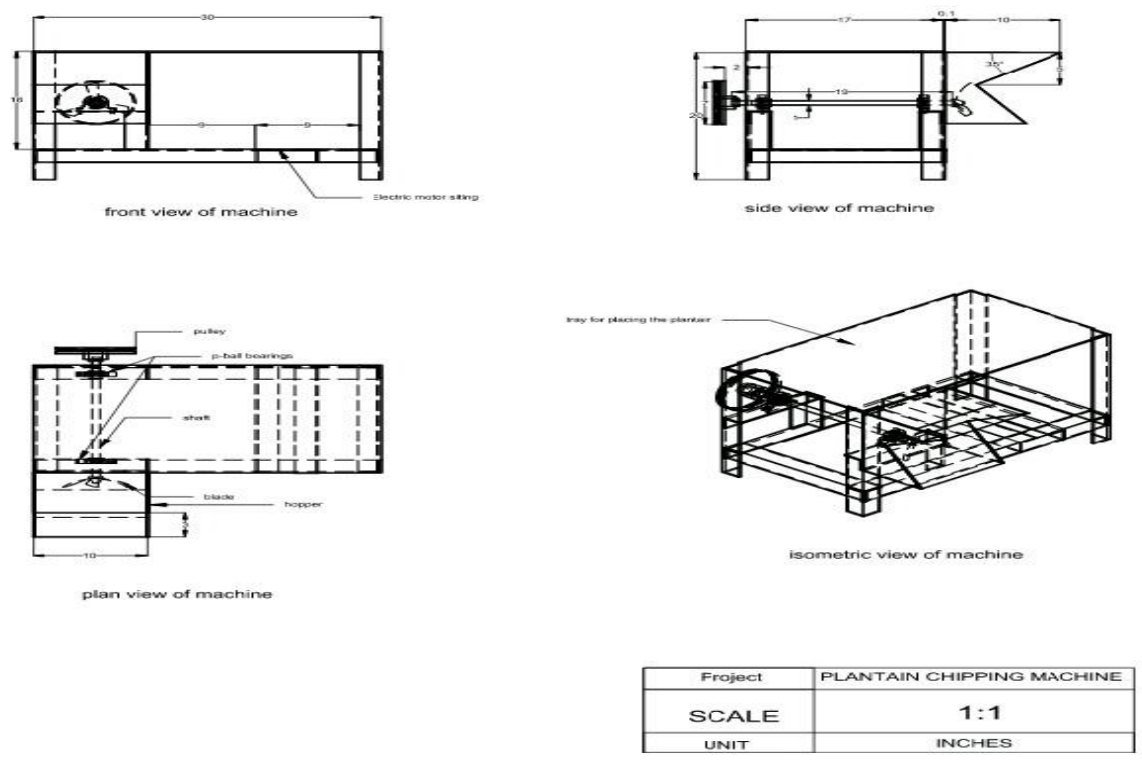

Figure 1. Orthographic View of the Plantain Chipping Machine 

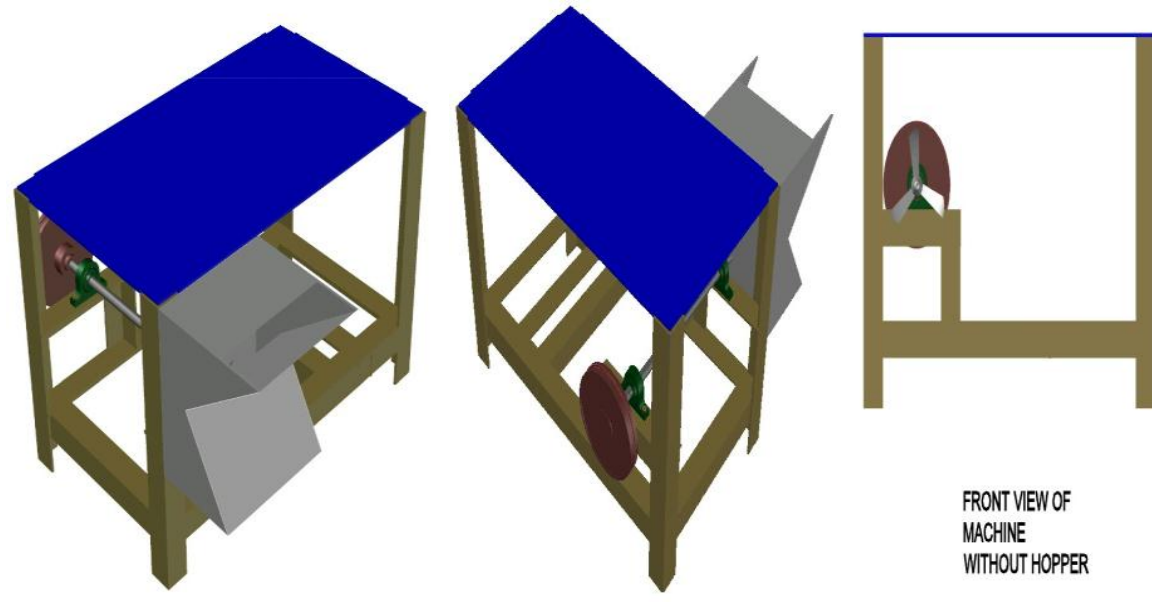

Figure 2. Orthographic Model of the Plantain Chipping Machine

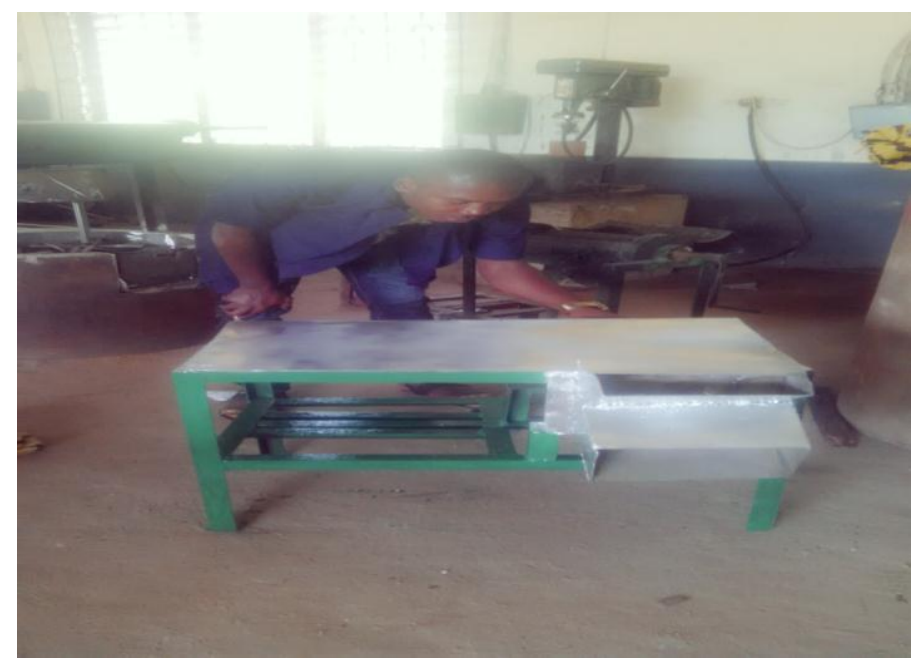

Figure 3. The Developed Plantain Chipping Machine

\section{Design Analysis}

Volume of hopper: The hopper is triangular prism in shape and tilts at an angle at the base towards the cutting disc or flywheel. This triangular prism shape of the hopper is also maintained in the discharge chute. This concept is preferred because of the concept of repose angle and the coefficient of friction of plantain which must be maintained for it to freely fall into the flywheel. The eq. (1) shows the formula for calculating volume of hopper. 


$$
\begin{aligned}
& V_{\text {intake }}=\frac{1}{2} a \times c \times h \\
& \mathrm{a}=17.78 \mathrm{~cm} \\
& \mathrm{c}=20 \mathrm{~cm} \\
& \mathrm{~h}=22.86 \mathrm{~cm} \\
& \text { Where } \\
& V_{\text {intake }} \text { Is the volume at the intake chute } \\
& \frac{1}{2} a \times c \text { Is the base area of the triangular prism } \\
& \mathrm{h} \text { is the height of the prism } \\
& \text { Therefore; } \\
& V_{\text {intake }}=\frac{1}{2} 17.78 \times 20 \times 22.86 \\
& V_{\text {intake }}=8129.016 \mathrm{~cm}^{3} \\
& \text { The hopper is half a prism, hence: } \\
& V_{\text {intake }}=0.5 \times 8129.016=4064.5 \mathrm{~cm}^{3}
\end{aligned}
$$

Repose angle $\emptyset$ : This is the angle at which the plantain will slide down the slope of the hopper. It is shown in eq. (2).

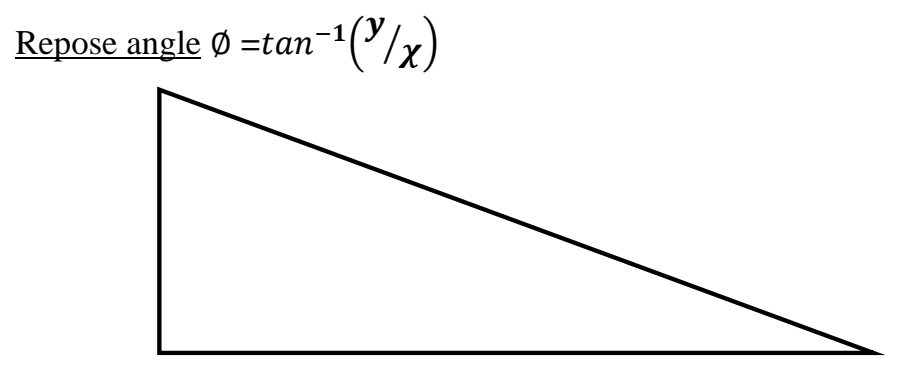

Figure 4. Relative Dimensions of the Hopper

Width of hopper $=22.86 \mathrm{~cm}$

$X=17.78 \mathrm{~cm}$

$Y=$ ?

$H=20.32$

Using Pythagoras theorem as shown in eq.(3),

$$
\begin{aligned}
y^{2} & =H^{2}-x^{2} \\
& =y^{2}=20.32^{2}-17.78^{2} \\
& y^{2}=96.77339 y=9.8373772 \cong 10 \mathrm{~cm}
\end{aligned}
$$

Therefore, Repose angle $\emptyset=\tan ^{-1}(10 / 17.78)$

$$
\emptyset=\tan ^{-1}(10.363)=29.370 \simeq 30^{\circ}
$$

Hence the angle of repose is $30^{\circ}$ 
Area of sliding surface $($ As $):$ As $=$ width $\times$ Height $(H)$

$$
=22.86 \times 20.32 \text {, Area }=464.51 \mathrm{~cm}^{2}
$$

Assumed surface area of a finger of plantain from average measurement of width and length of various plantains of different species [6].

Width $=5.08 \mathrm{~cm}$

Height $(H)=22.86 \mathrm{~cm}$

Areaofplantain $(A p)=5.08 \times 22.86=116.1288 \mathrm{~cm}^{2}$

Area of Tray $(A t)$

Length of trayLt $=76.2 \mathrm{~cm}$

Breath of trayBt $=43.18 \mathrm{~cm}$

$$
A t=L t \times B t=76.2 \times 43.18 \text { At }=3290.316 \mathrm{~cm}^{2}
$$

Diameter of the shaft

This involves the selection of the actual shaft diameter that can withstand the stresses encountered by the machine during safe operation. American standard shear stress of shaft $\tau=56 \mathrm{mPa}$

Power $=1 \mathrm{hp}=0.746 \mathrm{~kW}=746 \mathrm{~W}$

But power $(\mathrm{P})$ as referenced in eq. $(5)=P=\frac{2 \pi N T}{60}$ and $\mathrm{T}=\frac{P \times 60}{2 \pi N}$

Where $\mathrm{T}$ is the torque hence $=\frac{746 \times 60}{2 \pi \times 1440}$

$\mathrm{T}=\frac{48760}{9048.96}=4.9 \mathrm{Nm}$

Recall that $T=\tau \cdot \frac{\pi}{16} \times D^{3}$

$$
\begin{aligned}
& \mathrm{T}=\text { torque } \\
& \tau=\text { shear stress } \\
& \mathrm{D}=\text { diameter of shaft } \\
& D^{3}=\frac{\tau . \pi}{16 \times T} \quad=D^{3}=\frac{56 \times 3.142}{16 \times 4.95} \\
& \mathrm{D}=2.22 \mathrm{~cm}
\end{aligned}
$$

\section{Cutting blade}

This is an integral part of the machine that slices the plantain. The size of chips is influenced by the cutting clearance and the speed of rotation of the blade. The clearance between the blade and the hopper $=5.18 \mathrm{~cm}$ therefore at the least and maximum speed, the obtainable sizes of plantain chips are at ranges of 2 and $5.5 \mathrm{~cm}$.

\section{Belt}

The length of belt otherwise known as effective belt length (Le) is a design parameter required for the selection of belt length to fit in sheave settings so as to avoid error that can lead to accidents. 
Effective length of belt can be gotten using the formula outlined by [7] in eq. (6) as;

$$
\begin{aligned}
& \quad L_{e}=2 c+1.57(D+d)+(D-d / 4 c)^{2} \\
& \mathrm{C}=41.91 \mathrm{~cm} \\
& \mathrm{D}=20.48 \mathrm{~cm} \\
& \mathrm{~d}=16.51 \mathrm{~cm} \\
& \text { Where; } \\
& L_{e}=\text { the effective belt length } \\
& \mathrm{C}=\text { the design distance between the two pulleys }(\mathrm{D} \text { and d) } \\
& \mathrm{D}=\text { the diameter of the driver pulley }(\mathrm{cm}) \\
& L_{e}=2(41.91)+1.57(20.48+16.51)+(20.48-16.5 / 4(41.91))^{2} \\
& \qquad L_{e}=140.67 \mathrm{~cm}
\end{aligned}
$$

\section{Capacity of the Machine}

The machine is designed to cut 1 finger of plantain in 4seconds. That is, capacity of the machine $=1$ plantain finger chipped in 4 seconds. A plantain finger weighs about $500 \mathrm{gms}$. This translates to $7500 \mathrm{gms}$ per minute or $450 \mathrm{~kg} / \mathrm{hr}$.

\section{Electric Motor Specifications}

A 1 Hp electric motor was selected for the machine because of the estimated power requirements for the chipping operation.

\section{RESULTS AND DISCUSSION}

After the fabrication of the machine its operational performance was evaluated. A Faced Centred Response Surface Methodology using Central Composite Design was used to design the experiments. This method is useful because it uses very few experimental runs to describe how the test variables affect the response. It also helps to determine the inter-relationships among the test variables on the response and also helps to describe the combined effects of all the test variables on the response [8]. In the tests, three factors namely speed of the machine, the number of blades and the inclination angle of the chipping blades were investigated as they affected the chipping efficiency of the machine. The regression analysis was carried out with Minitab 16 software, while the response surface graphs were plotted with Matlab R2015a software.

The chipping efficiency of the machine was obtained using the method outlined in eq. (7) by [9] as;

$$
Y=\frac{M-C}{M} \times 100
$$

Where, $\mathrm{Y}=$ chipping efficiency in percentage $(\%)$,

$\mathrm{M}=$ weight of plantains fed into the machine (gms)

$\mathrm{C}=$ weight of unchipped plantains (gms) 
In the design the linear, interactive and quadratic effects of the factors (independent variables) as they affect the response (chipping efficiency) were studied [10]. Three levels of each of the factors were studied. They are listed as follows;

(i) Three different speeds of the machine, namely;
a. $325 \mathrm{rpm}$
(b) $650 \mathrm{rpm}$
(c) $975 \mathrm{rpm}$

(ii) Three different inclination angles of the blades, namely;
a. 300
(b) 450
(c) 600

(iii) Three different numbers of chipping blades, namely;
a. 3 blades
(b) 6 blades
(c) 9 blades

Table 1. Experimental Variables Used in the Design

\begin{tabular}{lccc}
\hline \multicolumn{3}{c}{ Independent Variables } & Variable Levels \\
\hline Speed of machine (rpm), X1 & 975 & 650 & 325 \\
Blade inclination angles, X2 & $30^{\circ}$ & $45^{\circ}$ & $60^{\circ}$ \\
Number of chipping blades, X3 & 3 & 6 & 9 \\
Code Designation & 1 & 0 & -1 \\
Dependent Variable (Response) & & & \\
Chipping Efficiency (\%) Y & & & \\
\hline
\end{tabular}

The coding using the design is as follows; $1=$ highest factor, $0=$ medium factor and 1 =lowest factor

Table 2. Experimental Results of Independent Variables and Response in Coded Terms

\begin{tabular}{lllll}
\hline Runs & $X 1$ & $X 2$ & $X 3$ & $Y$ \\
\hline 1 & 0 & 0 & 0 & 60 \\
2 & -1 & 0 & 0 & 47 \\
3 & -1 & 1 & 1 & 56 \\
4 & 1 & 1 & -1 & 58 \\
5 & 1 & -1 & 1 & 70 \\
6 & -1 & -1 & 1 & 59 \\
7 & 1 & 1 & 1 & 68 \\
8 & 0 & 1 & 0 & 50 \\
9 & 0 & -1 & 0 & 46 \\
10 & 0 & 0 & 0 & 50 \\
11 & -1 & 1 & -1 & 47 \\
12 & 0 & 0 & 0 & 49 \\
13 & 0 & 0 & 0 & 48
\end{tabular}




\begin{tabular}{lllll}
\hline 14 & 0 & 0 & 0 & 50 \\
15 & 1 & -1 & -1 & 67 \\
16 & 1 & 0 & 0 & 67 \\
17 & 0 & 0 & -1 & 57 \\
18 & -1 & -1 & -1 & 46 \\
19 & 0 & 0 & 0 & 48 \\
20 & 0 & 0 & 1 & 68 \\
\hline
\end{tabular}

Table 3. Response Surface Regression: Y versus X1, X2, X3

\begin{tabular}{lllll}
\hline Term & Coef. & SE Coef. & $T$ & $P$ \\
\hline Constant & 51.8455 & 1.458 & 35.570 & 0.000 \\
$X 1$ & 7.5000 & 1.341 & 5.594 & 0.000 \\
$X 2$ & -0.9000 & 1.341 & -0.671 & 0.517 \\
$X 3$ & 4.6000 & 1.341 & 3.431 & 0.006 \\
$X 1 * X 1$ & 3.6364 & 2.557 & 1.422 & 0.185 \\
$X 2 * X 2$ & -5.3636 & 2.557 & -2.098 & 0.062 \\
$X 3 * X 3$ & 9.1364 & 2.557 & 3.573 & 0.005 \\
$X 1 * X 2$ & -1.1250 & 1.499 & -0.750 & 0.470 \\
$X 1 * X 3$ & -1.1250 & 1.499 & -0.750 & 0.470 \\
$X 2 * X 3$ & 0.3750 & 1.499 & 0.250 & 0.808 \\
$S=4.23983$ & & & & \\
$R-S q=87.15 \%$ & & & & \\
\hline
\end{tabular}

The regression equation is given as $\mathrm{Y}=51.85+7.50 \mathrm{X} 1-0.90 \mathrm{X} 2+4.60 \mathrm{X} 3+3.64 \mathrm{X} 1^{\wedge} 2$ -

$5.36 \mathrm{X} 2^{\wedge} 2+9.14 \mathrm{X} 3^{\wedge} 2-1.13 \mathrm{X} 1 \mathrm{X} 2-1.13 \mathrm{X} 1 \mathrm{X} 3+0.38 \mathrm{X} 2 \mathrm{X} 3$

Table 4. Analysis of Variance for $Y$

\begin{tabular}{cllllll}
\hline Source & DF & Seq $\boldsymbol{S S}$ & Adj SS & Adj $\boldsymbol{M S}$ & $\boldsymbol{F}$ & $\boldsymbol{P}$ \\
\hline Regression & 9 & 1219.19 & 1219.19 & 135.465 & 7.54 & 0.002 \\
Linear & 3 & 782.20 & 782.20 & 260.733 & 14.50 & 0.001 \\
$X 1$ & 1 & 562.50 & 562.50 & 562.500 & 31.29 & 0.000 \\
$X 2$ & 1 & 8.10 & 8.10 & 8.100 & 0.45 & 0.517 \\
$X 3$ & 1 & 211.60 & 211.60 & 211.600 & 11.77 & 0.006 \\
Square & 3 & 415.61 & 415.61 & 138.538 & 7.71 & 0.006 \\
$X 1 * X 1$ & 1 & 174.05 & 36.36 & 36.364 & 2.02 & 0.185 \\
$X 2 * X 2$ & 1 & 12.01 & 79.11 & 79.114 & 4.40 & 0.062 \\
\hline
\end{tabular}




\begin{tabular}{cllllll}
\hline$X 3 * X 3$ & 1 & 229.55 & 229.55 & 229.551 & 12.77 & 0.005 \\
Interaction & 3 & 21.38 & 21.38 & 7.125 & 0.40 & 0.759 \\
$X 1 * X 2$ & 1 & 10.13 & 10.13 & 10.125 & 0.56 & 0.470 \\
$X 1 * X 3$ & 1 & 10.12 & 10.12 & 10.125 & 0.56 & 0.470 \\
$X 2 * X 3$ & 1 & 1.12 & 1.12 & 1.125 & 0.06 & 0.808 \\
Residual Error & 10 & 179.76 & 179.76 & 17.976 & & \\
Lack-of-Fit & 5 & 74.93 & 74.93 & 14.986 & 0.71 & 0.639 \\
Pure Error & 5 & 104.83 & 104.83 & 20.967 & & \\
Total & $\mathbf{1 9}$ & $\mathbf{1 3 9 8 . 9 5}$ & & & & \\
\hline
\end{tabular}

The experimental variables and coding are shown in Table 1, while the experimental results with the independent variables (in coded terms) are shown in Table 2. The estimated regression coefficients for chipping efficiency versus speed of the machine, blade inclination angle and the number of blades are shown in Table 3, while the analysis of variance associated with the regression are shown in Table 4. From Table 3 , the linear effects of speed, the linear and quadratic effects of the number of blades significantly affected the chipping efficiency of the machine at $5 \%$ probability, $(\mathrm{P} \leq 0.05)$. These factors accounted for $87.15 \%$ of the variation in the chipping efficiency of the machine.

The analysis variance Table 4 also confirms the results. From the response surface graph in Fig. 5, the speed of the machine increased with the chipping efficiency, but decreased as the cutting blade angle is increased. From the response surface plot in Fig. 6 , the chipping efficiency increased as the number of cutting blades are increased. Also, the chipping efficiency increased with the speed of the machine. From Fig. 7, the number of cutting blades increased with the chipping efficiency.

However, the chipping efficiency was not affected by the blades inclination angles.

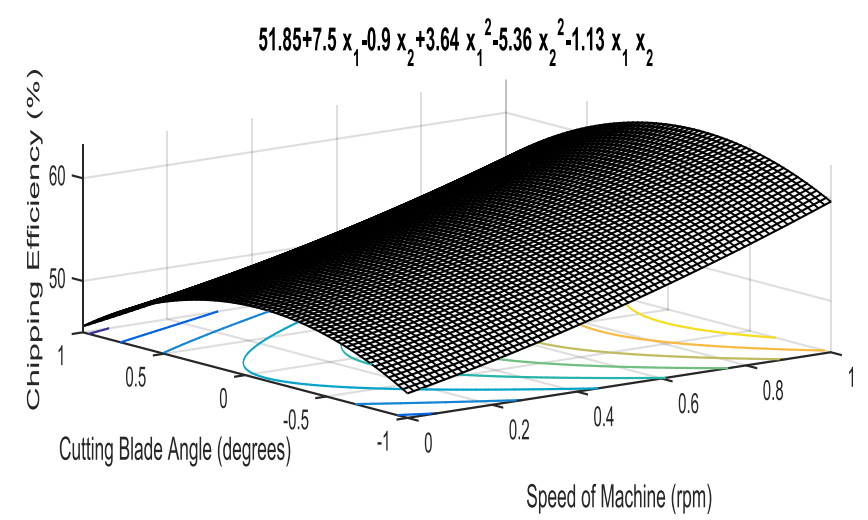

Figure 5. Response Surface Curve of the Effect of Cutting Blade Angle and Speed of Machine on the Chipping Efficiency of the Machine 


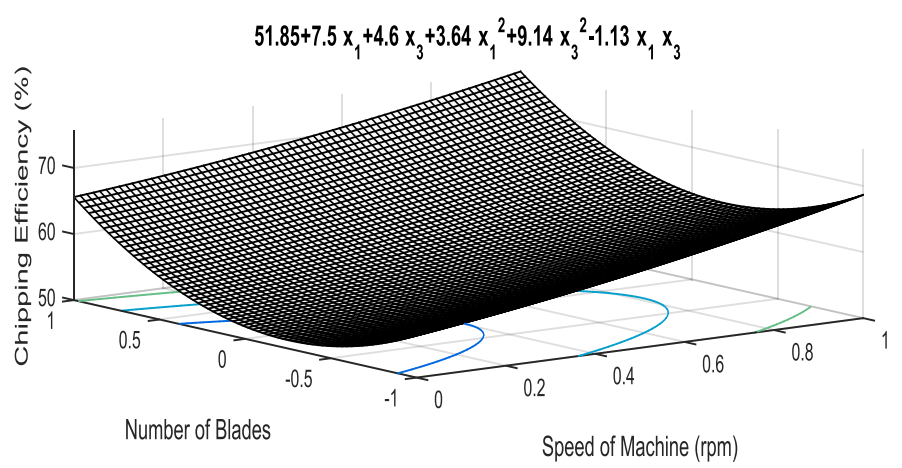

Figure 6. Response Surface Curve of the Effect of Number of Blades and Speed of Machine on the Chipping Efficiency of the Machine

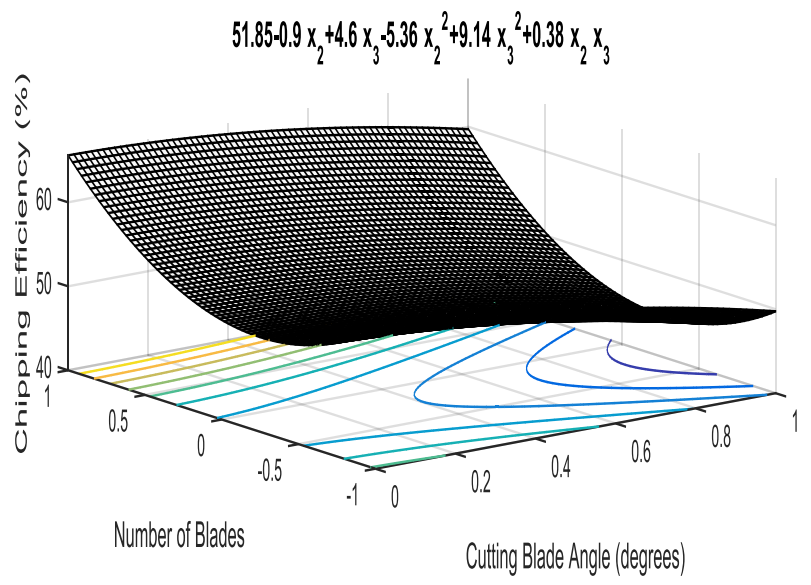

Figure 7. Response Surface Curve of the Effect of Number of Blades and Cutting Blade Angle on the Chipping Efficiency of the Machine

\section{CONCLUSIONS}

The machine performed satisfactorily during tests. It was observed that the machine produced uniform sized chips without discoloration and maintained good ergonomic characteristics in terms of noise and vibrations. 
The chipping efficiency increased as the numbers of cutting blades are increased. Also the chipping efficiency increased with the speed of the machine but was not affected by the inclination angles of the blades.

The linear effects of speed, the linear and quadratic effects of the number of blades significantly affected the chipping efficiency of the machine at $5 \%$ probability.

\title{
REFERENCES
}

[1] Arisa N.U, Adelekan A.O, Alamu A.E and Ogunfowora E.J. 2013. The Effect of Pretreatment of Plantain (Musa Parasidiaca) Flour on the Pasting and Sensory Characteristics of Biscuit, Int. Journal of Food and Nutrition Science.; 2(1): pp. 10-24.

[2] Maia Appleby. 2014. Plantain benefits. NASM-CPT, Demand Media. http://healthyeating.sfgate.com/plantainbenefits-5583.html, February 2020.

[3] www.healthline.com/plantains. 2020. Plantains: The Nutrition Facts and Health Benefits (Accessed 16 ${ }^{\text {th }}$ January, 2020.

[4] Raji, O. A. and Igbeka, J. C. 1994. Pedal Operated Chipping and Slicing Machine for Tuber. Journal of Agricultural Engineering Technology, 2: pp. 90 - 99.

[5] Henderson, S. M. and Perry, R. L. 1980. Agricultural Processing Engineering. Third edition. Macmillan Publishing Company, New York. pp. 185.

[6] Asoegwu SN, Nwandikom G.I, Nwammuo O.P. 1998. Some Mechanical Properties of Plantain Fruit. Int. Agrophysics. 12: pp. 67-77.

[7] Khurmi RS and Gupta J.K. 2005. A textbook of machine design (S. I. Units), Eurasia Publishing House (PVT.) Ltd., Ram Nagar, New Delhi-110055. 2005; 509-600, 677-714.

[8] Agriga A.N. and Iwe M.O. 2008. Physical Properties of Cookies Produced from Cassava, Groundnut-Corn Starch Blend. A Response Surface Analysis. Nigerian Food Journal 26(2) pp. 83-96.

[9] Ndirika V.I.O and Onwualu A.P. 2016. Design Principles for Postharvest Machines. $1^{\text {st }}$ Edition, Naphtali Prints, Lagos. Nigeria.

[10] Agriga, A.N. 2008. Development and Evaluation of Cassava-Groundnut Bars Using CornStarch as Binder.A Response Surface Analysis. Unpublished M.Sc. Thesis. Dept of Food Science and Technology. Michael Okpara University of Agriculture Umudike. pp. 38-43.

\section{RAZVOJ STABILNE MAŠINE SA MOTOROM ZA SITNJENJE DRVNIH OSTATAKA I PROCENA UČINKA METODOM ODREĐENIH POVRŠINA}

\author{
Ukachi J. Etoamaihe ${ }^{1}$, Sylvia O. Isaac ${ }^{2}$ \\ ${ }^{1}$ Department of Agricultural Engineering, Michael Okpara University \\ of Agriculture, Umudike, P. M. B. 7267, Umuahia, Abia State, Nigeria \\ ${ }^{2}$ Department of Mechanical Engineering, Abia State University, \\ Uturu, Abia State, Nigeria
}


Sažetak: Razvijena je stabilna mašina sa električnim motorom za usitnjavanje trupaca (stabala). Mašina ima: uređaj (mehanizam) za sečenje (lopatice-sečiva), mehanizam za privođenje delova drveta, ram i elektromotor kao izvor energije.

Mehanizam za sečenje sastoji se od specijalnih sečiva od nerđajućeg čelika, poluge, okvir za vođenje sečiva i remenice za pogon. Lopatice (sečiva) su postavljene normalno na pravac kretanja komada drveta (trupac).

Tokom procene performansi mašine sa primenom metodologije određene površine utvrđeno je da se efikasnost sečenja povećava ako se povećava broj sečiva. Takođe se efikasnost sitnjenja drveta povećavala sa porastom broja obrtaja rotora na kojem se nalaze sečiva, ali na efikasnost nisu uticali uglovi nagiba sečiva.

Linearni efekti brzine, linearni i kvadratni efekti broja sečiva značajno su uticali na efikasnost sečenja mašine za sitnjenje, sa verovatnoćom od $5 \%$.

Ključne reči: trupac, električni, motor, usitnjavanje, mašina, određena površina, metodologija.

Prijavljen:

Submitted:

16.03.2020.

Ispravljen:

Revised:

15.10.2020.

Prihvaćen:

Accepted:

26.10.2020. 